\title{
Indifference to Pain, Congenital, Autosomal Recessive
}

National Cancer Institute

\section{Source}

National Cancer Institute. Indifference to Pain, Congenital, Autosomal Recessive. NCI

Thesaurus. Code C125386.

A very rare, autosomal recessive inherited condition caused by mutations in the SCN9A gene. It is characterized by a lack of the ability to perceive physical pain. 